\title{
Trachyhystrichosphaera: An age-marker acanthomorph from the Bhander group, upper Vindhyan, Rajasthan
}

\author{
Purnima Srivastava \\ Centre of Advanced Study in Geology, Lucknow University, Lucknow 226 020, India. \\ e-mail: purnimasrivastava_51@rediffmail.com
}

\begin{abstract}
A highly diversified, advanced and exceptionally well preserved microfossil assemblage, dominated by a planktic community, has been recorded from petrographic thin sections of chert belonging to the Sirbu Shale Formation, Bhander group, upper Vindhyans, Rajasthan. Recently, it was noticed that the assemblage also contains well preserved, large-sized acanthomorphic acritarchs, Trachyhystrichosphaera considered to be an age-marker microfossil of the Cryogenian (850-630 Ma). It is reported for the first time from any Indian microfossil assemblage of Proterozoic succession. The other microfossils of the Sirbu Shale Formation are: well preserved simple, small and large-sized sphaeromorphs; complex acanthomorphs, cyanobacterial community; especially a very small-sized but exceptionally well preserved Obruchevella, a form resembling Volvox colonies; cf. vase-shaped microfossils and morphologies, possibly inclining towards fungal affinity, or lichenlike symbiotic associations of algae and fungi. Till date, Trachyhystrichosphaera has so far not been reported from successions older than the Tonian (1000-850 Ma). It is believed that acanthomorphs attained maximum size in Ediacaran (630-542 Ma), and further decreased in size in the Cambrian. The global paleontological literature indicates that Trachyhystrichosphaera ranges in age from Tonian-Ediacaran (1000-542 Ma).

The present record of Trachyhystrichosphaera as well as the earlier studies of micro and megascopic life of the Bhander Group in general and the Sirbu Shale in particular (aided by the absence of any Cambrian fossil record) indicate that in all possibilities, age of the Sirbu Shale should lie near Cryogenian (850-630 Ma) and the uppermost Bhander group, may incline towards the Ediacaran (630-542 Ma).
\end{abstract}

\section{Introduction}

It is now believed that the key to understand the early evolution of eukaryotes lies in the Proterozoic fossil record. The dominating microbial communities of this time were cyanobacteria, which show conservatism throughout the geological record. Other microbial communities are represented by protists, many of which are categorized as acritarchs. These are a heterogeneous, polyphyletic collection of organic-walled microfossils of unknown biological affinities. Morphologically, these forms exhibit a central cavity enclosed by a wall of single or multiple layers, chiefly of organic composition (Evitt 1963). Acritarchs can also be defined as vegetative and reproductive walls of unicellular protists, predominantly phytoplanktonic (Knoll 1994; Vidal and Moczydlowska-Vidal 1997). A large number of Proterozoic acritarchs are demonstrably benthic (Butterfield 1997, 2001) and of larger size compared to their Phanerozoic counterparts. Huntley et al (2006) inferred that "Acritarch body size increased significantly by the middle/late Cambrian (though not to the size seen in the Late Neoproterozoic)". They also inferred that "data do not support a monotonic increase in maximum diameter of acritarch vesicles through the Proterozoic; instead the maximum vesicle

Keywords. Acanthomorph; Bhander group; age-marker; upper Vindhyans; Rajasthan; Trachyhystrichosphaera. 


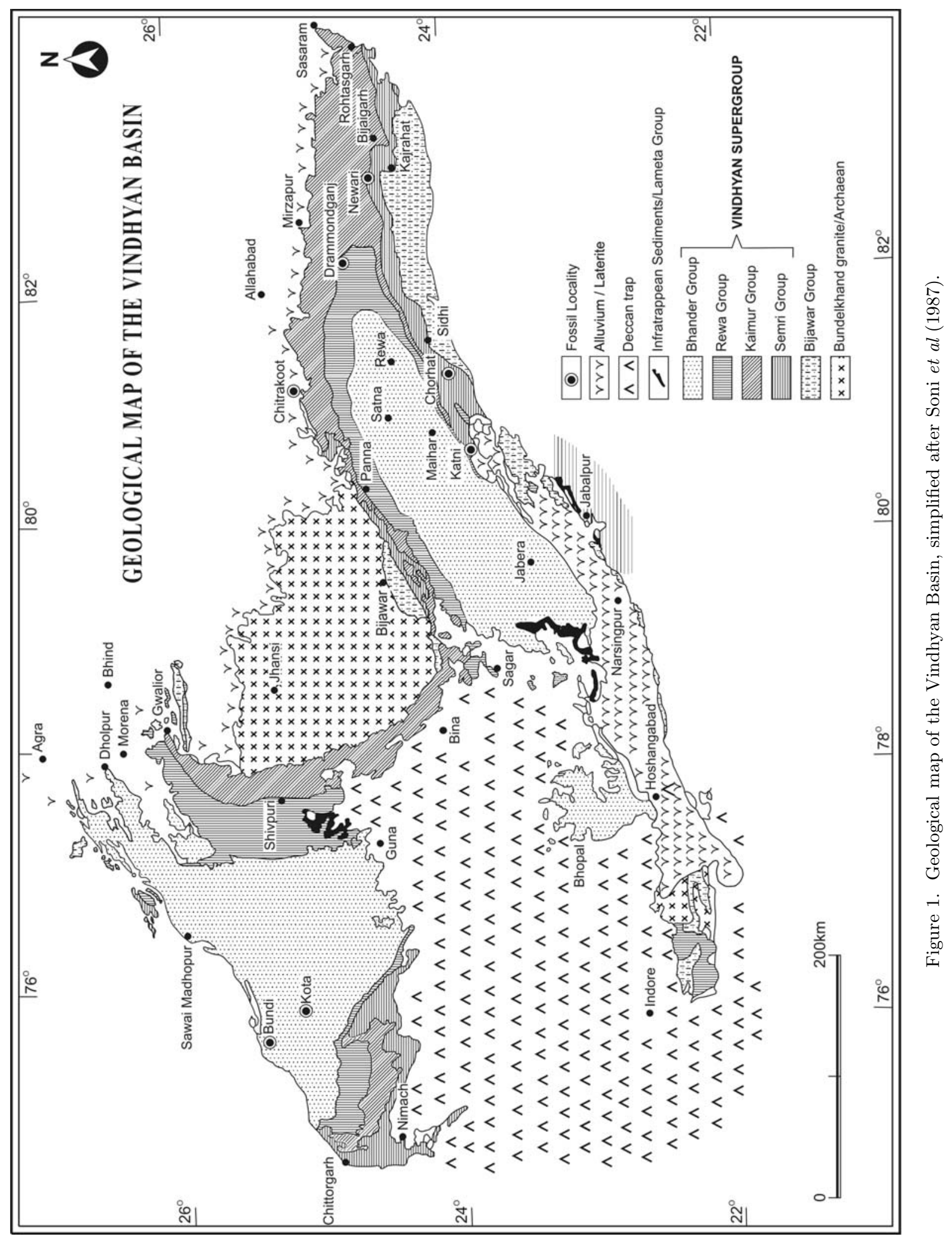


Table 1. Generalised lithostratigraphy of the Vindhyan Supergroup (following Prasad 1984).

\begin{tabular}{|c|c|}
\hline Bhander Group & $\begin{array}{l}\text { Dholpura Shale } \\
\text { Balwan Limestone } \\
\text { Maihar Sandstone/Upper Bhander } \\
\text { Sandstone } \\
\text { Sirbu Shale } \\
\text { Bundi Hill Sandstone } \\
\text { Samria Shale } \\
\text { Lakheri Limestone/Bhander } \\
\text { Limestone } \\
\text { Ganurgarh Shale }\end{array}$ \\
\hline Rewa Group & $\begin{array}{l}\text { Upper Rewa Sandstone } \\
\text { Jhiri Shale } \\
\text { Lower Rewa Sandstone } \\
\text { Panna Shale }\end{array}$ \\
\hline Kaimur Group & $\begin{array}{l}\text { Dhandraul Quartzite } \\
\text { Scarp Sandstone and Conglomerate } \\
\text { Bijaigarh Shale } \\
\text { Susnai Breccia } \\
\text { Upper Quartzite } \\
\text { Lower Quartzite }\end{array}$ \\
\hline Semri Group & $\begin{array}{l}\text { Rohtas Formation } \\
\text { Kheinjua Formation/Chorhat } \\
\text { Formation } \\
\text { Porcellanite Formation } \\
\text { Kajrahat Limestone } \\
\text { Basal Formation } \\
\text { Unconformity }\end{array}$ \\
\hline Bijawar Group & Phyllites \\
\hline
\end{tabular}

diameter appears to fluctuate in the Proterozoic before decreasing significantly in the early Cambrian". They are very useful in biostratigraphic correlation, as well as in paleobiogeographic and paleoenvironmental studies (Knoll and Butterfield 1989; Mendelson and Schopf 1992).

The genus Trachyhystrichosphaera was established by Timofeev et al (1976) for microfossils from the upper Riphean Lakhanda Formation of eastern Siberia. According to Butterfield et al (1994), Trachyhystrichosphaera is restricted to the Late Riphean. The other occurrences are: from the Shorikha Formation, Siberia (Neoproterozoic age, Sergeev 1999); from the Scotia Group, Hunnberg Formation and Svalbard (upper Riphean-Vendian age, Knoll 1984, 1992). Knoll (1996), listed it as being present in the Tonian (1000-850 Ma), which may also range into the Cryogenian (850-630 Ma); from the Tindir group, Alaska, (upper Riphean, Allison and Awramik 1989); from the Turukhansk uplift, Siberia (late Riphean age, Sergeev 1999); from the Officer Basin, Australia (Ediacaran age, Willman and Moczydlowska 2007; Zang 1995) and from the Xiaofenghe section of the Doushantou Formation, China, where the genus possibly extends to just above the Nantuo glaciation ( $\sim 580$ million years, Ediacaran age, Yin et al 2007; Zhou et al 2007). Golubkova and Raevskaya (2005) suggested $600 \mathrm{Ma}$ age (base of Ediacaran) for the genus, recorded from Russia. Therefore, the genus is now known to occur globally in rocks of Tonian to Ediacaran (1000-542 Ma) age.

Tappan (1980) suggested that the vesicleproducing stage of Trachyhystrichosphaera was metabolically active and capable of continued growth. Among extant algae this phenomenon is seen in the prasinophycean algae. The life cycle of prasinophytes alternates between a motile phase and a nonmotile, phycoma-producing stage (with a degradation-resistant wall that expands as the enveloped cell grows).

According to Knoll (1984), Trachyhystrichosphaera is one of the most complex acritarch known from Precambrian successions. It is considered as a eukaryote, but its systematic position is still not clear.

According to Butterfield (2005), the absence of excystment structures and evidence of vegetative growth (processes) in some acritarchs may indicate their multicellular grade of organization. Germinosphaera, Tappania and Trachyhystrichosphaera are the representative forms of such organization. He has also suggested a fungal affinity for Trachyhystrichosphaera.

Well-preserved micro and megafossils represented by; cyanobacteria, acritarchs, carbonaceous megafossils, have already been reported from Bhander group, upper Vindhyan (Kumar and Srivastava 1997, 2003; Prasad 2007). Ediacara fauna is reported from the Lakheri Limestone and Sirbu Shale Formations of the Bhander group, exposed in central India (De 2003, 2006) and from the Bundi Hill Sandstone, the Bhander group, Rajasthan (Srivastava 2006, Prof. H J Hofmann, convinced with the identification of few disc-shaped fossils Aspidella, in a personal communication). Beltanelliformis (body fossil) and Arumberia (a typical organo-sedimentary structure) of Ediacaran or latest Neoproterozoic age (Glaessner and Walter 1975; Mcllroy and Walter 1997; Mcllroy et al 2005) is also recorded from the Maihar Sandstone, central India (Kumar and Pandey 2008a, 2008b). The present paper reports well preserved process-bearing acritarchs Trachyhystrichosphaera from the petrographic thin sections of chert, belonging to the Sirbu Shale Formation, Bhander group, Rajasthan.

\section{Geological setting}

The Vindhyan Supergroup is about 4000 meters thick, and is the least metamorphosed sedimentry 


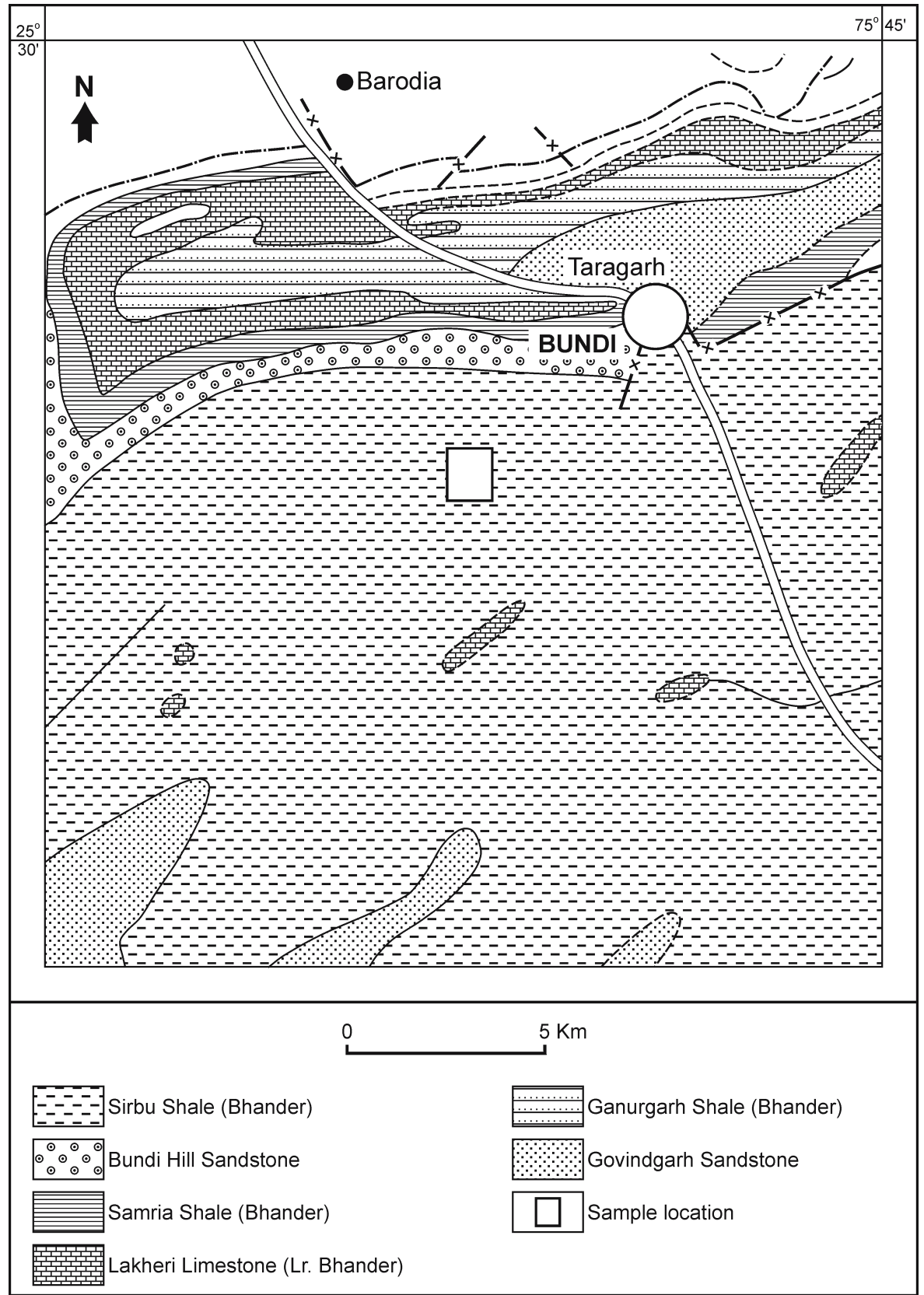

Figure 2. Geological map of the Sirbu Shale showing the sample location of the fossiliferous chert (simplified after Prasad 1984).

succession in central India. It is distributed in a sickle-shaped pattern around the Bundelkhand Massif (Auden 1933), in total occupying an area of about $104,000 \mathrm{~km}^{2}$ (figure 1). The exposures occur in patches, forming elevated hillocks and extended ridges on flat terrains in parts of Madhya Pradesh, Uttar Pradesh, Bihar and Rajasthan states. The supergroup is conventionally subdivided into four groups, viz., the Semri group, the Kaimur group, the Rewa group and the Bhander group (Sastry and Moitra 1984; Prasad 1984; Soni et al 1987). Each group is further divided into formations and members (see table 1). Traditionally the Semri group is synonymous with lower Vindhyan, whereas the other three groups are under upper Vindhyans. Overall lithology is represented by calcareous, argillaceous and aerenaceous sedimentary rocks (figure 2). The supergroup unconformably overlies the Bundelkhand Granite and metasediments of the Bijawar group, and is about $2500 \mathrm{Ma}$ in age (Crawford and Compston 1970; Mandal et al 2002).

In Rajasthan, the Sirbu Shale Formation is well developed and exposed in parts of Bundi district. It is conformably underlain by the Bundi Hill Sandstone and overlain by the upper Bhander 


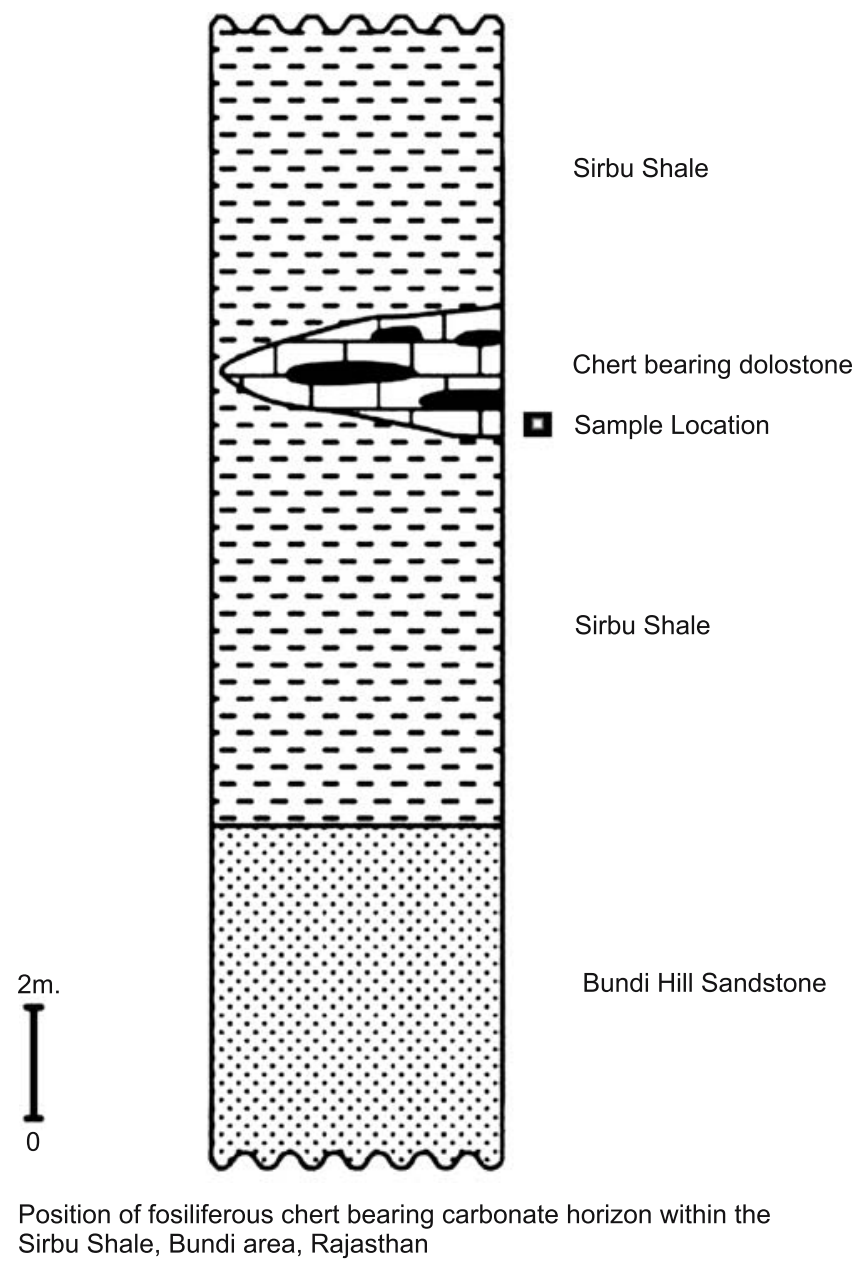

Figure 3. Lithological column of the Sirbu Shale containing fossil bearing chert.

Sandstone (figure 2). Samples of fossil-bearing chert have been collected from an outcrop, exposed exactly at the $6 \mathrm{~km}$ mark from Bundi, along the Bundi-Chittorgath road. Chert occurs in the form of thin lenses in between the dolomitic limestone/dolostone (stromatolitic at palces) associated with microbial laminites (figure 3 ). The lithostratigraphic succession of the Vindhyan Supergroup in Son Valley, central India and Chambal Valley, Rajasthan (following Prasad 1984) is given in table 1.

\section{Age of the Vindhyan Supergroup}

Age of the Vindhyan Supergroup is still a matter of debate, especially the upper age limit. Conventionally, it is considered to be Palaeo-Neoproterzoic (see Venkatachala et al 1996; Sharma 2003). Record of triploblastic animal traces (Seilacher et al 1998) and small shelly fauna (Azmi 1998), created a hot debatable issue (Brasier 1999; Kerr 2002; Conway Morris et al 1998; Hofmann 2005). On the basis of data available, age dispute of the lower Vindhyans is almost resolved, but age of the upper Vindhyans is still debatable (Ray 2006; Malone et al 2008).

\section{Methodology and repository}

Microfossils, including Trachyhystrichosphaera have been studied in petrographic thin sections of chert, collected from the fossil bearing horizon of study area (figure 2). Photomicrographs have been taken using the Leica-Quantimat microscope. Reference thin sections have been deposited in the Museum, Centre of Advanced Study in Geology, University of Lucknow, Lucknow, India.

\section{Morphological description}

The microfossil assemblage of the Sirbu Shale Formation, Rajasthan comprises a number of processbearing acritarchs (acanthomorphs). Among these acritarchs, possibly an age-marker form, identified as Trachyhystrichosphaera, consists of a largesized-organic-walled vesicle with sparsely placed, unbranched, hollow processes, prominent inner body and well preserved double wall (figure 4A). Very little difference is marked among the two species of this particular genus, viz., Trachyhystrichosphaera aimika (Timofeev et al 1976), which has no outer membrane, only the inner membrane is present, whereas outer and inner membranes are well preserved in Trachyhystrichosphaera vidalii (Knoll 1984). Allison and Awramik (1989) erected a new species T. magna on the basis of vesicles' large size. The author agrees with Butterfield et al (1994) in placing T. vidalii as a junior synonymy of $T$. aimika and interprets that the difference in both species may be taphonomic. In all three species, the morphology is represented by a spheroidal vesicle with tubular, non-septate, hollow processes (figure 4B, F, G) originating from the inner vesicle wall. Processes have no internal septum to separate the process interior from the vesicle lumen. Processes are cylindrical and slightly taper towards the apex (figure 4B, F, G). The diameter of the vesicles varies between $290-625 \mu \mathrm{m}$ in the present assemblage (figure 4A, E). The inner body is preserved in one specimen (figure 4A, $\mathrm{C})$. Folding can be seen in both the outer and inner wall (figure 4D). The length of processes varies between 15 and 45 microns, the width varies between 6 and 12 microns (figure 4B, F, G). In the present assemblage, although there are four such acanthomorphs, three of them resembling Trachyhystrichosphaera aimika, one exhibits larger size, comparable to T. magna (other features are comparable to T. aimika) and one with T. vidalii. However, considering their implication for age 

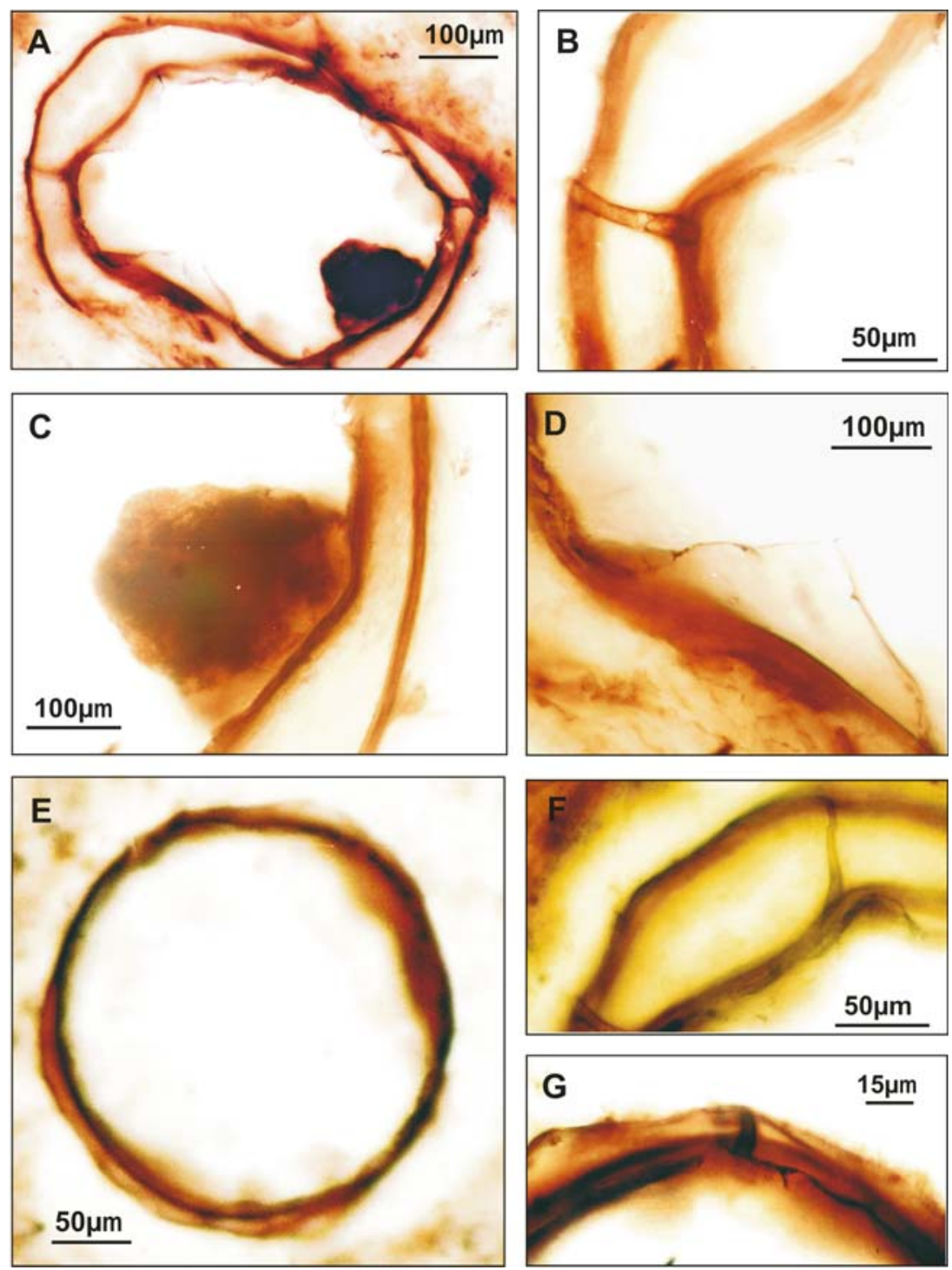

Figure 4. Photomicrographs of Trachyhystrichosphaera sp. with and without inner body, showing a magnified view of the processes, wall structure and inner body. (A) Trachyhystrichosphaera sp., slide no. Bn-3, co-ordinates 16.4/ 71.4. (B) Cylindrical process extending to the outer membrane and showing a distal opening, there is no tapering at distal end, slide no. Bn-3, co-ordinates 16.4/ 71.4. (C) Inner body, slide no. Bn-3, co-ordinates 16.4/ 71.4. (D) Folding in inner wall, slide no. Bn-3, co-ordinates 16.4/ 71.4. (E) Trachyhystrichosphaera sp. without inner body, slide no. Bn-3, co-ordinates 18.7/ 68.9. (F) Process tapered at distal end, slide no. Bn-3, co-ordinates 16.4/ 71.4, and (G) Bud-like process, slightly tapered at outer margin, slide no. Bn-3, co-ordinates 18.7/ 68.9.

estimation at generic level, these are not being further classified and described at specific level.

\section{Discussion and conclusion}

Trachyhystrichosphaera displays an inner body, which is also preserved in the present assemblage. It was interpreted that each vesicle probably consisted of a single large cell, which was metabolically active, altering the morphology of its vesicle as it grew.

The large size is consistent with a eukaryotic, possibly prasinophyte algal origin. Exceptionally large specimens (>600 microns), likely to be comparable with prasinophytes to some extent (Tappan 1980; Vidal and Knoll 1983).

The absence of excystment structures and the evidence for vegetative growth (processes) in some acritarchs may indicate multicellular grade of organization, Butterfield (2005).

According to Butterfield (2005), "Trachyhystrichosphaera has long defied taxonomic placement despite its distinctive morphology". He considered it to be of fungal affinity. Trachyhystrichosphaera is characterized by:

- a conspicuously large and variable central vesicle, 
- a conspicuously variable number and distribution of heteromorphic, usually open ended processes,

- absence of excystment structures,

- a tendency to develop outgrowth from the central vesicle, sometimes to the extent of forming secondary vesicles (this feature is not observed among the specimens of present assemblage).

Butterfield (2005) compared Trachyhystrichosphaera, with Tappania (a branched processes bearing acritarch), and suggested that the two taxa may share a common body plan to some extent, except distal branching in processes of Tappania. According to Butterfield and Rainbird (1998), "Trachyhystrichosphaera can be considered as an index fossil for latest Neoproterozoic period". They may be useful in biostratigraphic correlation, as well as palaeobiogeographic and palaeoenvironmental studies (Sergeev 1999). Because acritarchs represent the fossil record of the base of the marine food chain during the Proterozoic and Paleozoic, they must have played an important role in the evolution of the global marine ecosystem. According to Sergeev (2006), acanthomorphs are biostratigraphically significant organisms for both late Riphean and Palaeozoic. Yin et al (2007), suggested $\sim 580 \mathrm{Ma}$ age for Trachyhystrichosphaera, reported from the Xiaofenghe section of the Doushantuo Formation, China, on the basis of stratigraphic distribution of large acanthomorphs.

In addition to Trachyhystrichosphaera, the other significant microfossils of the Sirbu Shale assemblage are: Cymatiosphaera, Trachyhysphaeridium, leiosphaerids and large-sized unidentified, ornamented vesicles, a small species of Obruchevella, specimens cf. vase-shaped microfossils and Volvox colonies (Srivastava, unpublished data). Presence of Trachyhystrichosphaera and ornamented acritarchs $(>600 \mu \mathrm{m}$ to $1000 \mu \mathrm{m}$ in diameter) in the Sirbu Shale assemblage, and their comparison with other global occurrences, may suggests its age near Cryogenian (850-630 Ma). Ediacaran fossils (De 2003, 2006, Srivastava - unpublished data), along with Beltanelliformis and Arumberia reported from the Bhander group (Kumar and Pandey 2008a, 2008b), are the supporting parameters for the age estimation of the Bhander group. All these evidences collectively suggest, that the uppermost Bhander group of the Vindhyan Supergroup, may possibly lie near Ediacaran age (630-542 Ma), which may also represent the upper age limit for the Vindhyan Supergroup.

\section{Acknowledgements}

The author is thankful to Prof. N L Chhabra, Head, Centre of Advanced Study in Geology,
Lucknow University, Lucknow for providing the working facilities. The results are a part of the study carried out for DST's WOS-A Project, No. SR/WOS-A/ES-12/ 2003, awarded to the author.

\section{References}

Allison C W and Awramik S M 1989 Organic-walled microfossils from earliest Cambrian or latest Proterozoic Tindir Group rocks, northwest Canada; Precamb. Res. 43 253-294.

Auden J B 1933 Vindhyan sedimentation in Son Valley, Mirzapur district; Geol. Surv. India Memoir. 62 141-250.

Azmi R J 1998 Discovery of Lower Cambrian small shelly fossils and brachiopods from the Lower Vindhyan of Son Valley, Central India; J. Geol. Soc. India 52 381-389.

Brasier M 1999 Discovery of Lower Cambrian small shelly fossils and Brachiopods from the Lr. Vindhyan of Son Valley, Central India. Discussion; J. Geol. Soc. India $\mathbf{5 3}$ 727-730.

Butterfield N J 1997 Plankton ecology and the ProterozoicPhanerozoic transition; Palaeobiology 23 247-262.

Butterfield N J 2001 Ecology and evolution of the Cambrian plankton; Pp. 200-216; In: Ecology of the Cambrian Radiation (eds) Zhuralev A Yu and Riding R, Columbia University Press, New York.

Butterfield N J 2005 Probable Proterozoic Fungi; Palaeobiology 31 165-182.

Butterfield N J, Knoll A H and Swett K 1994 Paleobiology of the Neoproterozoic Svanbergfjellet Formation, Spitsbergen; Fossils and Strata 34 1-84.

Butterfield N J and Rainbird R H 1998 Diverse organicwalled fossils, including possible "dinofllagellates" from the early Neoproterozoic of arctic Canada; Geology 26(11) 963-966.

Crawford A R and Compston W 1970 The age of the Vindhyan system of peninsular India; J. Geol. Soc. London 125 351-371.

De C 2003 Possible organisms similar to Ediacaran forms from the Bhander Group, Vindhyan Supergroup, Late Neoproterozoic of India; J. Asian Earth Sci. 21 387-395.

De C 2006 Ediacaran Fossil assemblage in the Upper Vindhyans of Central India and its significance; J. Asian Earth Sci. 27 660-683.

Evitt W R 1963 A discussion and proposals concerning fossil dinoflagellates, hystrichospheres and acritarchs; II Proceedings of the National Academy of Sciences, USA 49 298-302.

Glaessner M F and Walter M R 1975 New Precambrian fossils from the Arumbera Sandstone, Northern Territory, Australia; Alcheringa 1 59-69.

Golubkova E and Raevskaya E 2005 Main changes in microfossil communities throughout the Upper Proterozoic of Russia; In: Precambrian to palaeozoic Palaeopalynology and Palaeobotany (eds) Steemans and Javaux; Notebooks on Geology, Best Memoir, 2005/02.

Hofmann H J 2005 Palaeoproterozoic dubiofossils from India Revisited - Vindhyan triploblastic animal burrows or pseudofossils? J. Palaeontol. Soc. India 50(2) 113-120.

Kerr R A 2002 Earliest animal trace or just mud cracks; Science 295 1209-1210.

Knoll A H 1984 Microbiotas of the Late Precambrian Hunnberg Formation, Nordoustlandet, Svalbard; J. Palaeontol. 58(1) 131-162.

Knoll A H 1992 Vendian microfossils in metasedimentary cherts of the Scotia Group, Prins Karls Foreland, Svalbard; Palaeontology 35(4) 751-774. 
Knoll A H 1994 Proterozoic and early Cambrian protists: Evidence for accelerating evolutionary tempo; Proceedings of the National Academy of Sciences, USA 91 6743-6750.

Knoll A H 1996 Chapter 4: Archaean and Proterozoic palaeontology; In: Palynology: Principles and applications, (eds) Jansonius J and McGregor D C American Association of Stratigraphic Palynologists Foundation 1, (Salt Lake City Publishers Press) 51-80.

Knoll A H and Butterfield N J 1989 New Window on Proterozoic life; Nature 337 602-603.

Kumar S and Pandey S K 2008a Arumberia and associated fossils from the Neoproterozoic Maihar Sandstone, Vindhyan Supergroup, Central India; J. Palaeontol. Soc. India 53(1) 83-97.

Kumar S and Pandey S K 2008b Discovery of organicwalled microbiota from the black-bedded chert, Balwan Limestone, the Bhander Group, Lakheri area, Rajasthan; Curr. Sci. 94(6) 797-800.

Kumar S and Srivastava P 1997 A note on the carbonaceous megafossils from the Neoproterozoic Bhander Group, Maihar area, M. P; J. Paleontol. Soc. India 42 141-146.

Kumar S and Srivastava P 2003 Carbonaceous megafossils from the Neoproterozoic Bhander Group, Central India; Palaeontol. Soc. India 48 139-154.

Leiming Yin and Baode Guan 1999 Organic-walled microfossils of Neoproterozoic Dongjia Formation, Lushan County, Henan Province, North China; Precamb. Res. 94 121-137.

Malone S J, Meert J G, Banerjee D M, Pandit M K, Tamrat E, Kamenov G D, Pradhan V R and Sohl L E 2008 Palaeomagnetism and detrital Zircon Geochronology of the Upper Vindhyan Sequence, Son Valley and Rajasthan, India: A ca. $1000 \mathrm{Ma}$ Closure age for the Purana Basins? Precamb. Res. 164 137-159, doi: 10.1016/jprecamres.2008.04.004.

Mandal M E A, Goswami J N, Deomurari M P and Sharma K K 2002 Ion microprobe $\mathrm{Pb} / \mathrm{Pb}$ ages of zircons from the Bundelkhand Massif, northern India: Implications for crustal evolution of the Bundelkhand-Aravalli Supercontinent; Precamb. Res. 117 85-100.

Mcllroy D and Walter M R 1997 A reconsideration of the biogenicity of Arumberia banksi Glaessner and walter; Alcheringa 21 79-80.

Mcllroy D, Crimes T P and Pauley C J 2005 Fossils and mat grounds from the Neoproterozoic Longmyndian Supergroup, Shropshire, U K; Geological Magazine 142(4) 441-455.

Mendelson C V and Schopf J W 1992 Proterozoic and early Cambrian acritarchs; In: The Proterozoic Biosphere, (eds) J W Schopf and C Klein (Cambridge: Cambridge University Press) 219-232.

Morris S C, Jensen S and Butterfield N J 1998 Fossil discoveries in India: Continued. Science 282 No. 5392, 1265.

Prasad B 1984 Geology, sedimentation and palaeogeography of the Vindhyan southeastern Rajasthan; Geol. Surv. India Memoir 116(1) 1-107.
Prasad B 2007 Obruchevella and other terminal Proterozoic (Vendia) organic-walled microfossils from the Bhander Group (Vindhyan Supergroup), Madhya Pradesh; J. Geol. Soc. India 69 295-310.

Ray J S 2006 Age of the Vindhyan Supergroup: A review of recent findings; J. Earth Syst. Sci. 115(1) 1490160.

Sastry M V A and Moitra A K 1984 Vindhyan Stratigraphy: A Review; Geol. Surv. India Memoir 116(part II) 109-148.

Seilacher A, Bose P K and Pflüger F 1998 Triploblastic animals more than 1 billion years ago: Trace fossil evidence from India; Science $\mathbf{2 8 2}$ 80-83.

Sergeev V N 1999 Silicified microfossils from transitional Meso-Neoproterzoic deposits of the Turukhansk Uplift, Siberia; Bollettino della Societa Paleontologica Italiana 38(2-3) 287-295.

Sergeev V V 2006 The importance of Precambrian microfossils for Modern Biostratigraphy; Palaeontol. J. 40(5) S664-S673.

Sharma M 2003 Age of Vindhyans - Palaeobiological evidence: A paradigm shift (?); Palaeontol. Soc. India 48 191-214.

Soni M K, Chakraborty S and Jain V K 1987 Vindhyan Supergroup - A review; In: Purana Basins of India; Geol. Soc. India Memoir 6 87-138

Srivastava P 2002 Carbonaceous megafossils from the Dholpura Shale, Uppermost Vindhyan Supergroup, Rajasthan: An age implication; J. Palaeontol. Soc. India 47 97-105.

Tappan H 1980 The palaeobiology of plant protists; Freeman and Co., San Francisco, 1028 pp.

Timofeev B V, Hermann $\mathrm{T}$ N and Mikhailova M S 1976 Microfossils of the Precambrian, Cambrian and Ordovisian; Institute of Geology and Geochronology, Academy of Sciences, USSR, 106 p. (in Russian).

Venkatachala B S, Sharma M and Shukla M 1996 Age and life of the Vindhyans - Facts and conjectures; Geol. Soc. India Memoir 36 137-165.

Vidal G and Moczydlowska-Vidal 1997 Biodiversity, speciation and extinction trends of Proterozoic and Cambrian phytoplankton; Palaeobiology 23(2) 230-246.

Vidal G and Knoll A H 1983 Proterozoic plankton; Geological Society of America Memoir 163 256-277.

Willman S and Moczydlowska M 2007 Ediacaran acritarch biota from the Giles 1 drillhole, Officer Basin, Australia and its potential for biostratigraphic correlation; Precamb. Res. doi: 1016/j.precamres.2007.10.010.

Yin L, Zhu M, Knoll A H, Xunlai Yuan, Zhang J and Hu J 2007 Doushantuo Embryos preserved inside diapause egg cysts; Nature 446 661-663.

Zang Wen-Long 1995 Early Neoproterozoic sequence stratigraphy and acritarch biostratigraphy, eastern Officer Basin, South Australia; Precamb. Res. 74 119-175.

Zhou, Chuanming, Xie Guwei, Kathleen, McFadden, Xiao Shuhai and Yuan Xun-lai 2007 The diversification and extinction of Doushantuo-Pertatataka acritarchs in South China: Causes and biostratigraphic significance; J. Geol. 42(3-4) 229-262. 